\title{
Twenty-Year Reform of Teaching Biochemistry and Molecular Biology at Fourth Military Medical University in China
}

\author{
Jing Zhao*, Yan Li*, Bo Yan*, Lintao Jia, Xia Li, Lifeng Wang, Xinping Liu, Libo Yao\# \\ Department of Biochemistry and Molecular Biology, Fourth Military Medical University, Xi'an, China \\ Email:
}

Received 24 February 2014; revised 24 March 2014; accepted 30 March 2014

Copyright (C) 2014 by authors and Scientific Research Publishing Inc.

This work is licensed under the Creative Commons Attribution International License (CC BY).

http://creativecommons.org/licenses/by/4.0/

c) (i) Open Access

\begin{abstract}
Higher medical education in China is dually challenged by inadequate understanding of career motivation among high school graduates and by insufficient self-directed learning capability as a result of long-term exam-based education. Biochemistry and Molecular Biology is one of the most essential basic courses at Fourth Military Medical University (FMMU), but students usually feel torn to deal with it. We have been making efforts to improve teaching efficiency for over twenty years. Our teaching reform involves design of students-centered experimental course, reorganization of theoretical course and attempt to evoke critical thinking in class. A few tips are shared with regards to how to make the course of Biochemistry and Molecular Biology more rewarding.
\end{abstract}

\section{Keywords}

Twenty-Year Teaching Reform; Fourth Military Medical University; Chinese Medical Students; Exam-Based Education; Critical Thinking

\section{Introduction}

Biochemistry and Molecular Biology has witnessed an array of fundamental breakthroughs in life science over hundreds of years. It seems like a trunk highway leading us to a subtle microworld of cells. In China, higher education in life science refers to Biochemistry and Molecular Biology as one of the most essential required classes. According to distinct training objectives for different majors, teaching activities on Biochemistry and

${ }^{*}$ These authors contributed equally to this paper.
${ }^{\#}$ Corresponding author.

How to cite this paper: Zhao, J., et al. (2014) Twenty-Year Reform of Teaching Biochemistry and Molecular Biology at Fourth Military Medical University in China. Open Journal of Social Sciences, 2, 269-274. 
Molecular Biology have been directed to either a biological lane or a medical lane. As the teachers at Fourth Military Medical University (FMMU), it is truly important for us to think over how the course of Biochemistry and Molecular Biology can contribute to preparing students for their future careers in medicine [1]-[4]. The purpose of this paper is to give a brief historic review on the three phases of our teaching reform in the last two decades and share a few tips in our efforts to improve teaching efficiency. This retrospective analysis would be of significance in not only helping us to summarize the gain and the loss in the long run but also inviting more attention on evolvement of teaching modes among teachers in other medical universities.

\section{Student Background and Teaching Rationales at FMMU}

\subsection{Background of Chinese Medical Students}

There is a huge difference in entrance to medical schools between China and the United States, as a result of fundamental difference in higher medical education system. Unlike students in the US who have got bachelor's degree before starting medical schools, Chinese medical students are senior high school graduates. They have got used to exam-driven learning for fifteen years throughout kindergarten, primary school and high school. Homework seldom challenges them to search for information out of the scope of textbooks and to come up with personal opinions. Under the severe competition of entering a desired school and hunting for a good job, too much attention is paid to tests and scores which decide students' future. It is rooted in their minds that high score tips are to copy as exactly as what teachers tell in class, and that different opinions are risky and should be avoided.

In addition, due to limited life experience and knowledge, a considerable number of Chinese medical students made career choice according to their parents' suggestion with even little interest in medicine. It is misleading to emphasize financial and social benefit of being doctors instead of understanding real needs of patients. This job-and-goal mismatch causes lack of sense of responsibility and loss of motivation of active learning and independent thinking while schooling.

In brief, passive learning and aimlessness among students are the two major barriers that our higher medical education has to face.

\subsection{Rationales for Teaching Biochemistry and Molecular Biology at FMMU}

To meet student background, we have some rationales at FMMU to teach Biochemistry and Molecular Biology based on decades of teaching feedback. First, it is much easier for medical students to recall physiological function of biochemical pathways than structural details of thousands of intermediates in cells. Second, we would like to help students understand better pathological roles that biochemical reactions may well play upon a particular disease context [5] [6]. Third, it really matters to ensure that students develop an integrative view on biochemical network characteristic of homeostasis and dynamic adaptation, which will benefit them for sure when dealing with real patients [7] [8]. Taken together, our course design of Biochemistry and Molecular Biology is friendly, functional and critical.

\section{Twenty-Year Teaching Reform of Biochemistry and Molecular Biology at FMMU}

We have gone through over-20-year teaching reform on the course setting of Biochemistry and Molecular Biology. Basically, there are three phases in which our efforts are made on design of students-determined experimental course, reorganization of theoretical course and cultivation of critical thinking, respectively (Figure 1).

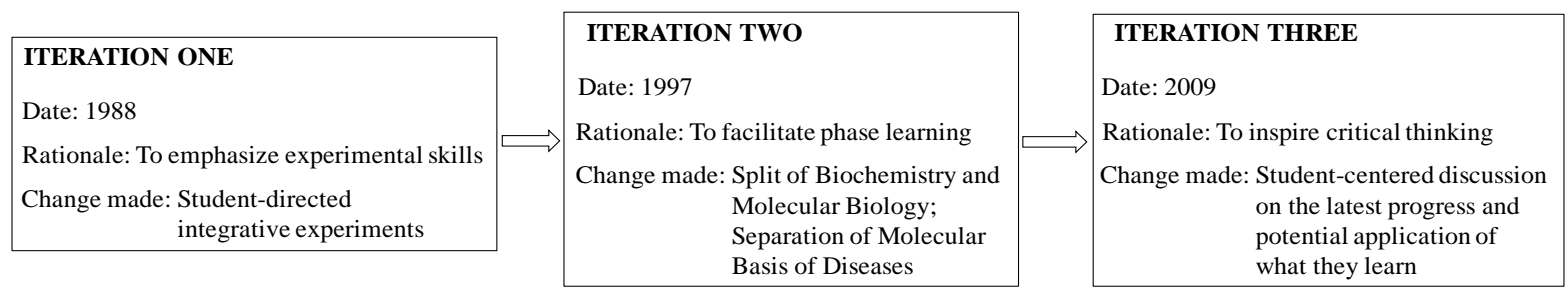

Figure 1. Three iterations of teaching biochemistry and molecular biology at FMMU. 


\subsection{First Iteration in Experimental Course Setting}

The first round of our teaching reform was traced back to the late 1980s when integrative experiments were encouraged. Students were assigned a particular project based on teaching plan, which usually required comprehensive knowledge and skills of several disciplines. With only limited help from teachers, students were responsible for designing workflow of experiments independently, carrying out the whole process from reagent preparation to readout judgment, and giving rise to a reasonable conclusion and explanation. The students-centered experimental course did a very good job on enabling them to make their own choice on how to solve a problem [9]. At that time, this idea of integrative experiments was also adopted by other courses like physiology and immunology, which turned out to be a heavy burden to students. Since the late 1990s, students-directed integrative experiments have converged on a special course and only allowed to carry out at Teaching Experimental Center. As a result, separate experiments of Biochemistry and Molecular Biology have been geared to the basics of proteins and nucleic acids (Table 1 ).

\subsection{Second Iteration in Theoretical Course Setting}

In the second phase of our teaching reform in the late 1990s, we primarily focused on optimization of theoretical course. The reason for us to do so was due to explosively increasing new concepts and technologies that made the textbook of Biochemistry and Molecular Biology thicker and thicker. Students kept complaining how nervous they were when final exam approached and how depressed when they had too much to go over at a time. In their eyes, Biochemistry and Molecular Biology seemed like a nightmare.

To relieve the pressure, one step we took was to separate Molecular Biology from Biochemistry, leading to two independent courses with two separate tests at the end of each course. The split of Biochemistry and Molecular Biology potentiated two-phased study and made it easier to attain phase goal. Students benefited from the course separation not only by feeling stress relieved but also by giving better performance in exams. As compared with the average grade of 260 students on the original Biochemistry and Molecular biology course from 1994 to 1996, the average grade of 420 students on all the split courses from 2005 to 2007 tended to rise a little bit (Figure 2), with variation expressed as SD bars.

The other improvement we made was to reorganize disease-related molecular biology in 2008. It was of note that there existed some novel topics such as oncogenes, tumor suppressor genes, gene diagnosis and gene therapy in modern molecular biology teaching. Students started to learn Biochemistry and Molecular Biology at $3^{\text {rd }}$

Table 1. The experimental course of biochemistry and molecular biology at FMMU.

\begin{tabular}{ccc}
\hline Modules & Experiment Topics \\
\hline Proteins & Denaturation, coagulation and precipitation of proteins \\
& Purification, quantification and functional identification of proteins \\
Nucleic acids & Separation, purification and quantification of DNA and RNA from tissues \\
& Molecular cloning of genes of interest into prokaryotic expression vectors \\
\hline
\end{tabular}

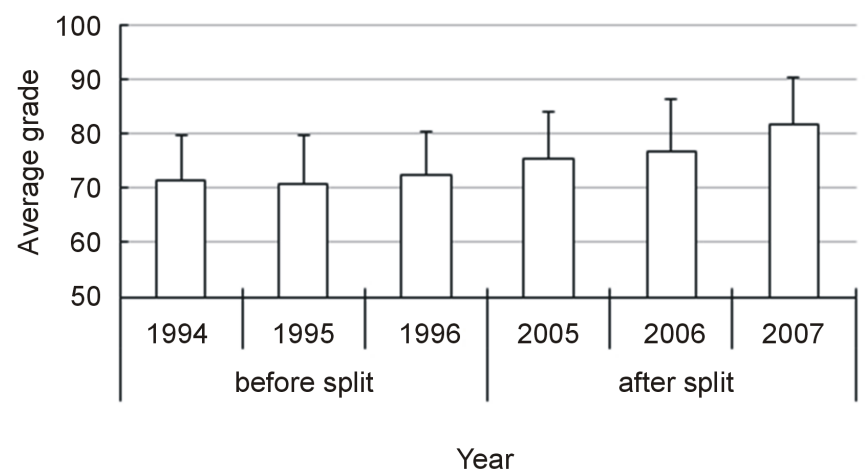

Figure 2. Grade comparison before and after the split of biochemistry and molecular biology at FMMU. 
semester right after anatomy and cell biology, when they did not touch physiology, pathology and immunology which were scheduled at $4^{\text {th }}$ semester. Inadequate background knowledge of basic medicine made students feel rather confused about those clinic-relevant parts. Given this awkward situation, we boldly put the molecular basis of diseases backward until $5^{\text {th }}$ semester, prior to the start of clinic medical courses. Table 2 shows the detailed lectures arranged for the disease section, which have been better received by senior students according to the feedback after class.

\subsection{Third Iteration in Evoking Critical Thinking}

The third phase of our teaching reform has been initiated by educational internationization since 2009. As an old saying goes, imagination is more important than knowledge. Unfortunately, traditional test-oriented education denies disagreement with authorities and almost kills students' imagination. With more training opportunities abroad for FMMU teaching faculty, we come to realize that it is essential and urgent to inspire students to think critically [10]. For this purpose, we begin trying harder to teach students how to fish rather than give them a fish.

Take the teaching plan on metabolism for example. We have got inflexible ways to interest students in the metabolic field (Table 3). Among those, discussion class is the most popular. Students are encouraged to present their personal perspectives with PowerPoint Slides within 7 minutes, with around 12 speeches in each class. The audience of other students is welcomed to ask questions and minidiscussion may occur in the middle [11] [12]. Teachers serve as facilitator instead of guider in every aspect of discussion class including group assignment, topic choice, PowerPoint preparation, oral presentation, brainstorming discussion and decision on winner list.

Out of several rounds of discussion class every year, it appears how to select right topics is a key to successful discussion. Initially students talked about whatever they were interested in the Biochemistry course and the audience hardly figured out the interrelationship of those talks, which resulted in inefficient communication. Then we narrowed discussion topics down to metabolism-based diseases. As a matter of fact, it did work better but students tended to introduce common symptom-treatment disease axis without deep thinking of the underlying molecular basis. This led us to a rethinking of topic choice on cancer cell metabolism, given a rapid advance in extensive mechanistic studies in this field. Students were divided into several groups and looked at cancer metabolism features from different point of views on carbohydrate metabolism, lipid metabolism, amino acid metabolism, oncogenes and tumor suppressor genes, respectively. In each group, there was a leader who showed a

Table 2. The section of molecular basis of diseases at $5^{\text {th }}$ semester.

\begin{tabular}{ccc}
\hline Chapters & Lecture Topics & Class Hours \\
\hline 1 & Genes and diseases & 2 \\
3 & Molecular basis of infectious diseases & 2 \\
4 & Molecular basis of inflammation & 2 \\
6 & Molecular basis of cardiovascular diseases & 2 \\
7 & Molecular basis of stress-related diseases & 2 \\
\hline
\end{tabular}

Table 3. Teaching organization on metabolism.

\begin{tabular}{|c|c|c|c|}
\hline Types & Objectives & Activities & Time \\
\hline Lectures & The basics of metabolic pathways & $\begin{array}{l}\text { Teacher-oriented talk, with open questions for } \\
\text { students }\end{array}$ & In class \\
\hline Discussion class & $\begin{array}{l}\text { Latest research progress and application } \\
\text { of metabolism }\end{array}$ & $\begin{array}{l}\text { Student-oriented talk, with little help from } \\
\text { teachers }\end{array}$ & In class \\
\hline Case analysis & Metabolism-relevant diseases & $\begin{array}{l}\text { Student-oriented task, to answer questions raised } \\
\text { in the network course }\end{array}$ & After class \\
\hline Homework & Integrative view of metabolic network & $\begin{array}{l}\text { Student-oriented task, to draw crosstalks of } \\
\text { metabolism }\end{array}$ & After class \\
\hline
\end{tabular}


whole picture of the section and each group member gave a detailed talk on one point of the picture. The reorganized discussion class was a big success. Students updated themselves with a lot of the latest researches and got more insight on how to acquire knowledge outside the class and how to think critically [13] [14].

\section{Tips for Improving Teaching Efficiency}

Our twenty-year reform has satisfactorily improved teaching efficiency. The latest feedback survey indicates that 53\% students consider Biochemistry and Molecular Biology as their favorite course and that $37 \%$ like some chapters because they like teaching styles of particular teachers.

We have a few tips to make Biochemistry and Molecular Biology education more rewarding. Most importantly, try to make the class as interesting as possible. The most effective way to interest students is to make them feel this course truly useful in both daily life and future medical career. For example, when it comes to amino acid metabolism, we ask some questions "is an egg-and-milk-only breakfast sufficient or not?" "Why are some people milk-sick?" "What is the reason for someone to add melamine to food proteins?" "How can metabolic abnormality of proteins cause diseases like hyperammonemia, megaloblastic anemia and albinism?” Such questions are beneficial for arousing students' passion to learn.

Next, treat students as active thinkers rather than passive recipients [15]. There is a tremendous unknown world beyond textbooks and we would love to learn together with students. We respect every question they raise and sing high praise for their independent thinking. We listen to what they get out of updated resources and encourage them to think over both contribution and limitation of the present studies. The intimate cooperation between teachers and students brings out the best of students.

\section{Conclusions}

In our twenty-year teaching efforts, Biochemistry and Molecular Biology has been structurally optimized and functionally oriented to meet the needs of medical students. The current course setting includes two required theoretical courses (Biochemistry, Molecular Biology), one required experimental course (manipulation of proteins and nucleic acids), one selective theoretical course (molecular basis of diseases), and students feel much easier to adapt themselves to this step-by-step learning as showed by $92 \%$ satisfaction (593 out of 645) with the present teaching calendar last year. More importantly, the current teaching modes are more flexible and effective by adding student-centered discussion class, case analysis in network course and homework on particular projects to traditional lectures, and as a result students are more interested and motivated in active learning as indicated by $90 \%$ positive feedback (53\% preference for the whole course and $37 \%$ for certain chapters) among 645 students.

Despite these encouraging progresses, there are still some issues that need further attention. Especially for discussion classes, we still lack detailed evaluation criteria for both students' performance and teachers' guidance. Also we have to think over how to integrate Biochemistry and Molecular Biology into a bigger picture of Cellular and Molecular Basis of Life, enabling a better mechanistic understanding of the relevance of molecular events to cell behaviors and of basic medicine to clinical diseases. More advanced approaches such as problem-based learning would also be considered in the future teaching activities in order to further improve students' self-learning abilities [16]-[18].

\section{Funding}

This work is partially supported by FMMU Teaching Project (JG201006) to Libo Yao.

\section{References}

[1] Burge, S.M. (2003) Undergraduate Medical Curricula: Are Students Being Trained to Meet Future Service Needs. Clinical Medicine, 3, 243-246. http://dx.doi.org/10.7861/clinmedicine.3-3-243

[2] Maudsley, G. and Strivens, J. (2000) Science, Critical Thinking and Competence for Tomorrow’s Doctors: A Review of Terms and Concepts. Medical Education, 34, 53-60. http://dx.doi.org/10.1046/j.1365-2923.2000.00428.x

[3] Grande, J.P. (2009) Training of Physicians for the Twenty-First Century: Role of the Basic Sciences. Medical Teacher, 31, 802-806. http://dx.doi.org/10.1080/01421590903137049

[4] Norman, G. (2012) Medical Education: Past, Present and Future. Perspectives on Medical Education, 1, 6-14. 
http://dx.doi.org/10.1007/s40037-012-0002-7

[5] Sitaraman, R. (2012) From Bedside to Blackboard: the Benefits of Teaching Molecular Biology within a Medical Context. Perspectives in Biology and Medicine, 55, 461-466. http://dx.doi.org/10.1353/pbm.2012.0030

[6] Surapaneni, K.M. and Tekian, A. (2013) Concept Mapping Enhances Learning of Biochemistry. Medical Education, 18, 1 -4.

[7] Schauber, S.K., Hecht, M., Nouns, Z.M. and Dettmer, S. (2013) On the Role of Biomedical Knowledge in the Acquisition of Clinical Knowledge. Medical Education, 47, 1223-1235. http://dx.doi.org/10.1111/medu.12229

[8] Kulasegaram, K.M., Martimianakis, M.A., Mylopoulos, M., Whitehead, C.R. and Woods, N.N. (2013) Cognition before Curriculum: Rethinking the Integration of Basic Science and Clinical Learning. Academic Medicine, 88, 15781585. http://dx.doi.org/10.1097/ACM.0b013e3182a45def

[9] Finnerty, E.P., Chauvin, S., Bonaminio, G., Andrews, M., Carroll, R.G. and Pangaro, L.N. (2010) Flexner Revisited: The Role and Value of the Basic Sciences in Medical Education. Academic Medicine, 85, 349-355. http://dx.doi.org/10.1097/ACM.0b013e3181c88b09

[10] Elizondo-Omaña, R.E., Morales-Gómez, J.A., Morquecho-Espinoza, O., Hinojosa-Amaya, J.M., Villarreal-Silva, E.E., García-Rodríguez, M.L. and Guzmán-López, S. (2010) Teaching Skills to Promote Clinical Reasoning in Early Basic Science Courses. Anatomical Sciences Education, 3, 267-271. http://dx.doi.org/10.1002/ase.178

[11] Sé, A.B., Passos, R.M., Ono, A.H. and Hermes-Lima, M. (2008) The Use of Multiple Tools for Teaching Medical Biochemistry. Advances in Physiology Education, 32, 38-46. http://dx.doi.org/10.1152/advan.00028.2007

[12] Azer, S.A., Guerrero, A.P. and Walsh, A. (2013) Enhancing Learning Approaches: Practical Tips for Students and Teachers. Medical Teacher, 35, 433-443. http://dx.doi.org/10.3109/0142159X.2013.775413

[13] Krupat, E., Sprague, J.M., Wolpaw, D., Haidet, P., Hatem, D. and O’Brien, B. (2011) Thinking Critically about Critical Thinking: Ability, Disposition or Both? Medical Education, 45, 625-635. http://dx.doi.org/10.1111/j.1365-2923.2010.03910.x

[14] Tiwari, A., Lai, P., So, M. and Yuen, K. (2006) A Comparison of the Effects of Problem-Based Learning and Lecturing on the Development of Students' Critical Thinking. Medical Education, 40, 547-554. http://dx.doi.org/10.1111/j.1365-2929.2006.02481.x

[15] Ludmerer, K.M. (2004) Learner-Centred Medical Education. New England Journal of Medicine, 351, 1163-1164. http://dx.doi.org/10.1056/NEJMp048112

[16] Gwee, M.C.E. (2008) Globalization of Problem-Based Learning (PBL): Cross-Cultural Implications. Kaohsiung Journal of Medical Sciences, 4, 14-22. http://dx.doi.org/10.1016/S1607-551X(08)70089-5

[17] Lian, J. and He, F. (2013) Improved Performance of Students Instructed in a Hybrid PBL Format. Biochemistry and Molecular Biology Education, 41, 5-10. http://dx.doi.org/10.1002/bmb.20666

[18] Vanderford, N.L. (2011) Broaden Undergraduate Education. Biochemistry and Molecular Biology Education, 39, 251-252. http://dx.doi.org/10.1002/bmb.20520 